\title{
Beata Tarczydło
}

AGH Akademia Górniczo-Hutnicza

\section{Trendy w komunikacji marketingowej na rzecz marek - wybrane aspekty}

Kod JEL: M310

Słowa kluczowe: marka, komunikacja marketingowa, trendy, studia przypadków

Streszczenie. Celem artykułu jest podjęcie próby przybliżenia kierunków zmian we współczesnych działaniach komunikacji marketingowej na rzecz marek. Rozważania prowadzone będą wokół tezy - w drugiej dekadzie XXI wieku komunikacja marketingowa silnie zdeterminowana jest nadążaniem za uwarunkowaniami rynkowymi (w tym m.in. zmianami w zachowaniach i oczekiwaniach adresatów, postępem techniczno-technologicznym czy rozwojem funkcjonalności oferowanych w internecie). Wychodząc od przybliżenia komunikacji marketingowej na rzecz marek obiektów rynkowych, wskazano współczesne uwarunkowania jej podejmowania i wdrażania. Następnie zaprezentowano rezultaty studiów literaturowych oraz przegląd dostępnych raportów i stanowisk badawczych z analizowanego obszaru. Opisano także wyniki przeprowadzonych badań pierwotnych z wykorzystaniem metody studium przypadku.

\section{Wprowadzenie}

W wyniku nasilającej się konkurencji i wyrównania poziomu technologicznego, kosztowo-cenowego, komunikacyjnego oraz informacyjnego nieodzownym wyróżnikiem rywalizacji rynkowej stała się niepowtarzalna marka. Nawiązując do teorii zasobowej zarządzania, marka jest zasobem strategicznym istotnie przyczyniającym się do osiągnięcia przewagi konkurencyjnej i rozwoju oznaczo- 
nego nią obiektu (np. osoby, produktu, organizacji). Marka i jej metodyczne budowanie (w tym wzmacnianie jej świadomości i kreowanie odpowiednich relacji z interesariuszami przez zróżnicowane formy komunikacji marketingowej online i offline) stały się ważnym paradygmatem współczesnego zarządzania marketingowego.

Celem artykułu jest przybliżenie zmian i wskazanie trendów w skutecznych działaniach z zakresu komunikacji marketingowej na rzecz marek. Wychodząc od przeglądu dostępnych źródeł literaturowych oraz internetowych, dla potrzeb artykułu wykonano badania własne, które objęły analizy/studia przypadków połączone $\mathrm{z}$ aktywnym uczestnictwem w przedsięwzięciach z obszaru komunikacji marketingowej dla wybranych marek. Wyniki badań własnych skonfrontowano z dostępnymi opiniami praktyków i innymi wynikami badań z analizowanego obszaru, co powinno być przydatne dla zarządzających markami współczesnych obiektów rynkowych. W efekcie nasunął się wniosek, że zintegrowane kampanie komunikacji marketingowej na rzecz spersonifikowanych marek z zastosowaniem strategii 360 stopni zdają się być optymalnym rozwiązaniem w obecnych warunkach rynkowych.

\section{Podstawowe pojęcia i ich charakterystyka}

Do podstawowych pojęć zaliczono: markę, obiekt rynkowy oraz zagadnienia dotyczące komunikacji marketingowej, które przybliżono w tabeli 1.

Tabela 1

Wybrane pojęcia i ich charakterystyka

\begin{tabular}{|l|l|}
\hline \multicolumn{1}{|c|}{ Pojęcia } & \multicolumn{1}{c|}{ Charakterystyka } \\
\hline $\begin{array}{l}\text { Obiekty rynkowe } \\
\text { oznaczane markami }\end{array}$ & $\begin{array}{l}\text { uczestnicy gry rynkowej, dla których podejmuje się działania komunikacji } \\
\text { marketingowej, czyli osoby, produkty, organizacje, miasta, gminy itd. }\end{array}$ \\
\hline & $\begin{array}{l}\text { w dostępnych źródłach informacji definiowana jest na różne sposoby; } \\
\text { K.L. Keller (2011) podaje, za American Marketing Association, że marka to } \\
\text { nazwa, termin, symbol, wzór lub ich kombinacja, stworzona w celu identy- } \\
\text { fikacji dóbr lub usług sprzedawcy albo ich grupy i wyróżnienia ich spośród } \\
\text { konkurencji; D.A. Aaker (2004) definiuje markę jako złożony symbol, nie- } \\
\text { uchwytną sumę cech; w obecnych warunkach rynkowych zasadne jest holi- } \\
\text { styczne (Kall, 2005) definiowanie marki, czyli rozpatrywanie jej jako kon- } \\
\text { glomeratu samej kategorii, która została nią oznaczona (np. osoba, organi- } \\
\text { zacja, produkt, miasto czy inny obiekt rynkowy) z oferowanymi przezeń ko- } \\
\text { rzyściami dla interesariuszy i wzbogaconymi o nieuchwytną, niematerialną } \\
\text { otoczkę; wykreowana marka o pozytywnym wizerunku dla konsumenta za- } \\
\text { lewanego ogromną ilością nowych informacji stanowi pewnego rodzaju dro- } \\
\text { gowskaz i gwarant dobrego wyboru }\end{array}$ \\
\hline $\begin{array}{l}\text { Model komunikacji } \\
\text { marketingowej }\end{array}$ & $\begin{array}{l}\text { obejmuje: nadawcę, odbiorcę, przekaz, kanał, sprzężenie zwrotne oraz kon- } \\
\text { tekst komunikacji (Wiktor, 2013, s. 15-24) }\end{array}$ \\
\hline $\begin{array}{l}\text { Tradycyjne i nowo- } \\
\text { czesne funkcje komu- } \\
\text { nikacji marketingo- } \\
\text { wej }\end{array}$ & $\begin{array}{l}\text { w przeszłości zadaniami komunikacji (promocji) było: informowanie (do- } \\
\text { starczanie obecnym i potencjalnym nabywcom informacji prowadzącej do } \\
\text { przełamania bariery nieznajomości rynku), pobudzanie popytu (kreowanie }\end{array}$ \\
\hline
\end{tabular}




\begin{tabular}{|c|c|}
\hline & $\begin{array}{l}\text { zamierzonych postaw i zachowań rynkowych nabywców) oraz funkcja kon- } \\
\text { kurencyjna (przez odpowiednie działania zakłócanie programów emitowa- } \\
\text { nych przez konkurencję i wyróżnianie się na jej tle); } \\
\text { w ujęciu nowoczesnym (Taranko, } 2015, \mathrm{~s} \text {. 27-30) do funkcji komunikacji } \\
\text { marketingowej zalicza się: edukowanie, redukowanie barier dostępu do } \\
\text { oferty, budowanie doświadczeń nabywcy z marką, zwiększanie zaangażo- } \\
\text { wania interesariuszy, kreowanie dodatkowych instrumentów rywalizacji na } \\
\text { rynku }\end{array}$ \\
\hline $\begin{array}{l}\text { Podstawowe czynniki } \\
\text { determinujące anali- } \\
\text { zowane działania }\end{array}$ & $\begin{array}{l}\text { specyfika i oczekiwania interesariuszy; postęp techniczno-technologiczny; } \\
\text { silna konkurencja; nadążanie za obecnymi trendami - cyfryzacją, rozwojem } \\
\text { funkcjonalności internetu i urządzeń mobilnych; sytuacja ekonomiczna } \\
\text { i wielkość obiektu rynkowego; przyjęte strategie rozwoju oraz system ce- } \\
\text { lów; rodzaj i charakter rynku; oferowany zbiór wartości; charakter popytu } \\
\text { oraz stopień jego elastyczności cenowej i dochodowej; rozwój badań nad } \\
\text { zachowaniami nabywców - neurobadania, doskonalenie narzędzi, metod } \\
\text { i procedur marketingowych; uwarunkowania prawne }\end{array}$ \\
\hline $\begin{array}{l}\text { Etapy budowy sku- } \\
\text { tecznej kampanii }\end{array}$ & $\begin{array}{l}\text { identyfikacja odbiorców komunikacji marketingowej, określenie celów, } \\
\text { projektowanie przekazu, wybór kanałów komunikacji, ustalenie całkowi- } \\
\text { tego budżetu, decyzje dotyczące communication mix, mierzenie rezultatów } \\
\text { działań }\end{array}$ \\
\hline Pomiar skuteczności & $\begin{array}{l}\text { polega na weryfikacji stopnia realizacji celów kampanii komunikacji mar- } \\
\text { ketingowej (Kotler, Keller, 2013, s. 529-530) }\end{array}$ \\
\hline
\end{tabular}

Źródło: opracowano na podstawie: Kall, 2005, s. 9; Keller, 2011, s. 20; Kotler, Keller, 2013, s. 529-530; Taranko, 2015, s. 27-30; Wiktor, 2013, s. 15-24.

Przybliżone pojęcia motywują do zastanowienia się oraz prześledzenia, czy i jak w praktyce gospodarczej zmieniają się działania promocyjno-komunikacyjne na rzecz marki obiektu rynkowego.

\section{Od promocji do holistycznej komunikacji marketingowej na rzecz marki}

W dostępnych źródłach natrafiono na następujące określenia: promocja, komunikacja marketingowa, zintegrowana komunikacja marketingowa, zintegrowana promocja marki, strategia komunikacji marketingowej 360 stopni oraz holistyczna komunikacja marketingowa.

Promocja to element działan marketingowych, obok produktu, ceny i dystrybucji. Istotą promocji jest przekazywanie informacji i może być niewystarczającym procesem szczególnie na chłonnym rynku. Im więcej szumów informacyjnych, tym większa potrzeba uzyskania informacji zwrotnej, stąd niezbędna jest komunikacja marketingowa, obejmująca zespół działań i środków, za pomocą których przedsiębiorstwo przekazuje na rynek informacje charakteryzujące obiekt rynkowy, kształtuje potrzeby nabywców, ukierunkowuje popyt oraz zmniejsza jego elastyczność cenową, przy czym akcent kładzie się na dwukierunkowe przepływy informacyjne, swoisty dialog i interaktywność (Wiktor, 2013, s. 7, 310-350). W tym ujęciu obszary decyzji nadawcy w procesie komunikacji z rynkiem powinny obejmować: formułowanie celów kampanii komuni- 
kacji marketingowej, identyfikację targetu - adresatów kampanii, ustalenie budżetu, określenie kompozycji instrumentów komunikacji oraz ocenę efektów kampanii komunikacyjnej.

Kolejny etap doskonalenia działań to zintegrowana komunikacja marketingowa (ZKM), która jest szerszą kategorią. Wartościowej systematyki cech zintegrowanej komunikacji marketingowej dokonała m.in. B. Iwankiewicz-Rak (2011, s. 101). Uwzględniając to podejście, opinię C. Hackley'a (2010, s. 72-90) oraz stanowisko Ph. Kotlera i K.L. Kellera (2013, s. 508-537), a także własne doświadczenia można stwierdzić, że ZKM obejmuje jako inicjatorów interesariuszy; jej cele ukierunkowane są na komunikowanie się i budowanie relacji; ogromnie ważna jest znajomość cech i oczekiwań uczestników; stopień zróżnicowania komunikatów skorelowany jest z oczekiwaniami interesariuszy; wykorzystuje model sieciowej ${ }^{1}$ komunikacji; obejmuje szerokie kanały, media i narzędzia komunikacyjne; opiera się na silnej koordynacji wszystkich przedsięwzięć; cechuje ją elastyczność przejawiająca się m.in. w wykorzystywaniu nadarzających się okazji; zorientowana jest na wymierne efekty, które poddawane są kontroli; zwykle dotyczy konkretnego przedsięwzięcia rynkowego; zależy od posiadanych środków i umiejętności pozyskania partnerów do wspólnych działań.

Kolejna forma profesjonalizacji analizowanych działań, która zdaje się dominować $\mathrm{w}$ aktualnych praktykach przedsiębiorców to zintegrowana promocja marki (integrated brand promotion - IBP), rozumiana jako proces zintegrowanych działań komunikacji marketingowej na rzecz marki (O'Guinn, Allen, Semenik, 2012, s. 13-14, 534-651).

Prowadzone studia literaturowe i badania empiryczne doprowadziły do kolejnej strategii w rozważanym obszarze, czyli 360 stopni. Nazwa oznacza kompleksowość w uwzględnieniu mediów i kanałów komunikacyjnych stosownie do możliwości wynikających z postępu w rozwoju technologii informacyjnych. Cechą wyróżniającą komunikację marketingową 360 stopni jest multimedialność. Chodzi o to, by odpowiednio dobrane narzędzia komunikacyjne obejmowały wszystkie dostępne media (masowe - prasa, radio, telewizja, internet oraz systemy komunikacji mobilnej - sms, mms i inne) celem niejako „otoczenia” interesariuszy komunikatami promocyjnymi w różnorodnych formach. Szczególnego znaczenia obecnie nabrała umiejętna komunikacja przez media społecznościowe (Bonek, Smaga, 2013, s. 11-172).

Należy podkreślić, że stosując strategię komunikacji marketingowej 360 stopni dąży się do osiągania celów komunikacyjnych sformułowanych na podstawie znajomości własnych zasobów, warunków działania i otoczenia konkurencyjnego, zgodnie z podejściem marketingowym zorientowanym na rynek, przy

\footnotetext{
${ }^{1} \mathrm{~W}$ praktyce gospodarczej nie tylko dochodzi do dwukierunkowego komunikowania się: organizacja/marka-interesariusze, ale i odwrotnie oraz interesariusze-interesariusze.
} 
uwzględnieniu metodycznie zaprojektowanych multimedialnych działań komunikacyjnych. Opisywana strategia komunikacji marketingowej 360 stopni na rzecz konkretnej marki niejako nadaje odrębność i charakter wdrażanym działaniom na tle innych kampanii komunikacyjnych. Zdaniem J. Szufnarowskiego (2016) kampania 360 stopni powinna uwzględniać: działania $\mathrm{ATL}^{2}$, $\mathrm{BTL}^{3}$, direct mail i consumer promotion oraz pocket media; social media; interactive; PR i mobile. Pisząc o wdrożeniu konkretnej tego typu kampanii, autor ten wylicza: strony internetowe i marketing w wyszukiwarkach SEM; direct marketing; social media marketing; reklamę internetową, w tym AdWords (system, który pozwala na wyświetlanie linków sponsorowanych w wynikach wyszukiwarki Google), banery i artykuły sponsorowane oraz tradycyjną reklamę. Odwołując się do działań profesjonalistów z rynku polskiego, w tym Stowarzyszenia Komunikacji Marketingowej SAR, warto wskazać media (tab. 2.), które brane są pod uwagę w ocenie zgłoszonych kampanii komunikacyjnych.

Tabela 2

Modelowy zakres mediów w kampanii komunikacji marketingowej 360 stopni

\begin{tabular}{|l|l|}
\hline \multicolumn{1}{|c|}{ Media/kategorie } & \multicolumn{1}{c|}{ Formy komunikacji marketingowej } \\
\hline Telewizja & spoty, branded content, product placement, sponsoring \\
\hline Radio & spoty, sponsoring, konkursy, program/content \\
\hline Druk & $\begin{array}{l}\text { magazyny, gazety, advertoriale, prasa handlowa, inserty, sampling } \\
\text { w prasie }\end{array}$ \\
\hline Kategoria direct & prezentacja produktu, listy, e-maile, telemarketing \\
\hline Public relations & różne narzędzia public relations \\
\hline Eventy & celebrowanie ważnych wydarzeń \\
\hline Kategoria produkt & komunikacja czasowa na opakowaniu \\
\hline Kino & on screen, off screen \\
\hline $\begin{array}{l}\text { Interactive } \\
\text { reklama internetowa, display, media społecznościowe, e-mail marke- } \\
\text { ting, wideo online, SEM/SEO, mobile marketing, strona internetowa, } \\
\text { reklama w grach, radio internetowe, tworzenie/użycie contentu, mar- } \\
\text { keting wirusowy, aplikacje/widety/gry, inne }\end{array}$ \\
\hline $\begin{array}{l}\text { Kategoria OOH } \\
\text { reklama zewnętrzna }\end{array}$ & $\begin{array}{l}\text { billboardy, transport, lotniska, nośniki ambientowe tworzone na po- } \\
\text { trzeby kampanii, inne }\end{array}$ \\
\hline Pokazy branżowe & targi, wystawy, pokazy sponsorowane \\
\hline Sponsoring & sponsoring/partnerstwo \\
\hline
\end{tabular}

${ }^{2}$ ATL (Above The Line) - działania prowadzone w mediach tradycyjnych typu telewizja, radio, prasa, plakaty, reklama zewnętrzna (outdoor), reklama wewnętrzna (indoor) itp. (Above_the_line ...).

${ }^{3}$ BTL (Below The Line) - działania skierowane do konkretnego adresata (np. detalisty, konsumenta); zalicza się do nich: materiały POS (point of sales) lub POP (point of purchase); akcje promocji sprzedaży; public relations; ambient media; sponsoring, formy marketingu bezpośredniego: direct marketing, direct mail itd.; sweepstakes - gry losowe, totalizator: loterie; quizy; zakłady bukmacherskie; tombole; gry na zgadywanie: zagadki, szarady; konkursy; sampling; product placement; event marketing; mobile marketing i bluetooth marketing; sprzedaż bezpośrednią; ambush marketing (także: parasite marketing), marketing pasożytniczy; marketing wirusowy; marketing partyzancki; optymalizacja dla wyszukiwarek internetowych; artykuły w mediach drukowanych (Below_the_line...). 


\begin{tabular}{|l|l|}
\hline $\begin{array}{l}\text { Kategoria handel de- } \\
\text { taliczny }\end{array}$ & $\begin{array}{l}\text { promocje sprzedaży, nośniki POS, in-store merchandising, nośniki } \\
\text { POS wideo, retailtainment }\end{array}$ \\
\hline Kategoria guerrilla & $\begin{array}{l}\text { ambient media, sampling/trial, street teams, happening, flash mob, } \\
\text { czyli sztuczny thum, projekcje multimedialne }\end{array}$ \\
\hline $\begin{array}{l}\text { Zaangażowanie kon- } \\
\text { sumentów }\end{array}$ & $\begin{array}{l}\text { WOM marketing szeptany, user generated content, marketing } \\
\text { wirusowy, blogi }\end{array}$ \\
\hline
\end{tabular}

Źródło: opracowanie na podstawie Effie Awards..., 2012, s. 173.

Usystematyzowany zakres mediów i form komunikacji marketingowej 360 stopni wskazują, jak wiele potencjalnie możliwych jest działań. Co więcej, rzeczywista lista nie jest zamknięta, gdyż zależy od pomysłowości twórców. Ciekawym rozwiązaniem są np. agenci zaufania, którzy m.in. przyczyniają się do rozgłosu (generują i rozpowszechniają informacje), inspirują do włączenia się do dyskusji, kreują pozytywne doświadczenia, wpływają na opinie i zachowania interesariuszy (Brogan, Smith, 2011, s. 20-31, 185-201).

Wreszcie holistyczna komunikacja marketingowa na rzecz oznaczonego marką obiektu rynkowego zdeterminowana jest odpowiednim podejściem do jej zaprojektowania i wdrożenia. Czynnikami istotnie wpływającymi na ostateczne rezultaty są: kreatywny pomysł, znalezienie partnerów, zaangażowanie specjalistów, znajomość preferencji nabywców w zakresie wartości eksponowanych w komunikacji (odwoływanie się do emocji i kreowanie doświadczeń), odpowiednia ilość czasu, środki na działania, ważne przesłanie, marka, dla której przygotowuje się strategię, interesariusze, cele, narzędzia (odpowiednie, innowacyjne, wyróżniające na tle konkurencji i trafnie dobrane dla adresatów), właściwe i multimedialne kanały komunikacyjne, harmonogram działań, skala przedsięwzięć zapewniająca podtrzymywanie uwagi adresatów, metody szacowania rezultatów oraz elastyczność. Takie działania mają na celu umiejętne motywowanie adresatów do wyboru konkretnej oferty rynkowej przez oddziaływanie na centralny układ nerwowy człowieka, w szczególności na mózg, a w nim na procesy świadome i podświadome. W centrum zainteresowania stawiają adresata, który w swoich zachowaniach kieruje się „rozumem, sercem i duchem”. Obejmują różnorodne techniki z uwzględnieniem zaangażowania interesariuszy, postępu techniczno-technologicznego czy rozwoju funkcjonalności internetu. Są też elementem zintegrowanych i multimedialnych działań marketingowych obiektu rynkowego.

Podsumowując, w okresie kilkudziesięciu lat praktyk marketingowych znacznie zmieniły się działania wspomagające promowanie oferty i komunikację $\mathrm{z}$ interesariuszami. Autorka szczególnie chce podkreślić, że w obecnych warunkach rynkowych działania te prowadzone są wokół/na rzecz spersonifikowanej marki. Dzieje się tak dlatego, że współczesne marki to złożone konstrukty, które istotnie przyczyniają się do sukcesu rynkowego danego podmiotu, jednak przy 
odpowiednich wysiłkach komunikacyjnych. Potwierdza to Pogorzelski (2015, s. 37-38.) akcentując znaczenie marki i wskazując model jej zewnętrznej siły.

Ważnym zjawiskiem w zarządzaniu marką jest jej personifikowanie (przypisywanie cech ludzkich; szerzej: Gorbaniuk, 2011), dzięki czemu „mogą one komunikować się" $\mathrm{z}$ interesariuszami, a nawet $\mathrm{w}$ pewnym sensie „wchodzić z nimi w relacje". Przyjmuje się, że osobowość marki (ang. brand personality) to przypisywany jej zbiór cech ludzkiego charakteru (Janiszewska, Kall, 2012, s. 135), przy czym zdolność interesariuszy do opisania marki wspomnianymi cechami zależy od tego, jak spójna i atrakcyjna jest dla nich tożsamość marki. Tożsamość marki wynika z kultury organizacyjnej jej właściciela, na którą składają się: wartości, normy, przekonania, postawy, założenia, zachowania i sposoby realizacji zadań. Osobowość marki pomaga osiągnąć odrębność nawet na zapełnionym rynku, pomaga budować relacje z partnerami (interesariuszami) i sprawia, że marka jest łatwiej zapamiętywana (Staszyńska, 2013, s. 39).

Odnosząc się do zjawiska komunikowania się marek z interesariuszami szczególnie modnym obecnie zjawiskiem jest ich angażowanie w projektowanie działań komunikacyjnych (Kasprzycki-Rosikoń, Piątkowski, 2013). Kolejna ważna praktyka to budowanie wirtualnej społeczności wokół spersonifikowanej marki (Tarczydło, 2011), w której aktywny udział biorą wszyscy zainteresowani.

Chcąc zweryfikować, jak teoria przekłada się na praktykę zdecydowano się na przeprowadzenie badań empirycznych.

\section{Wybrane aspekty komunikacji marketingowej analizowanych marek - wyniki badań}

Na potrzeby niniejszego opracowania zaprojektowano jakościowe badania wybranych marek z wykorzystaniem metody studium przypadku. Obiektami badawczymi były marki: Eurobank, H \& M, Ikea, Lidl, Orange, Tymbark i Żywiec. Ogólnie w projekcie zrealizowanym w pierwszym kwartale 2016 roku starano się zaobserwować narzędzia, metody i procedury komunikacji marketingowej na rzecz analizowanych marek oraz zidentyfikować charakterystyczne zjawiska/trendy w tym obszarze. W szczególności poszukiwano informacji: co to za marka, jak długo obecna jest na rynku, co jest przez nią oferowane; kto odpowiada za realizowaną strategię komunikacji marketingowej i kto ją wspomaga oraz w jakim stopniu; do kogo adresowane są działania komunikacyjne (co najmniej: pracownicy, klienci, przedstawiciele mediów itp.); czy i jakie wyniki badań są przydatne w polityce komunikacyjnej badanej marki; jaki jest zakres prowadzonych działań komunikacyjnych i jakie w uwzględnionym horyzoncie czasowym trwały kampanie, wydarzenia, eventy; jaki jest budżet na analizowane działania; jakie metody badania skuteczności komunikacji marketingowej są stosowane; czy i jakie inne/zaskakujące przedsięwzięcia z badanego obszaru były 
podejmowane. Uzyskano bogaty materiał opisowy (wybrane zagadnienia zawarto w tab. 3), co pozwala formułować pewne spostrzeżenia i wnioski, choć badań nie można uznać za reprezentatywne. Dołożono jednak starań, aby objęły różne branże. Wybrano znane marki, dla których prowadzone są rozbudowane działania komunikacji marketingowej.

Tabela 3

Wybrane charakterystyki komunikacji marketingowej badanych marek

\begin{tabular}{|c|c|}
\hline Marki & Komunikacja marketingowa marki w badanym okresie - wybrane informacje \\
\hline Eurobank & $\begin{array}{l}\text { Marka banku dla młodych, średnio zamożnych i zamożnych ludzi; działa na polskim } \\
\text { rynku już ponad dekadę; deklaruje działalność zorientowaną na zrozumienie potrzeb } \\
\text { i bliskie relacje z klientami digitalnymi (specyficzna komunikacja, celebryta Piotr Ad- } \\
\text { amczyk); nastawiony na rozwój obsługi online i nowoczesną bankowość elektro- } \\
\text { niczną, stąd główne jego cechy to internetowy i mobilny - zgodnie z hasłem „Euro- } \\
\text { bank na co dzień”. Specjalistyczne agencje zajmują się pozycjonowaniem marki Eu- } \\
\text { robank w wyszukiwarkach internetowych i treści z nią powiązanych, chodzi m.in. } \\
\text { o optymalizację stron internetowych, analizę słów kluczowych oraz budowanie sieci } \\
\text { linków. Zaobserwowane formy komunikacji marketingowej: serwis www; artykuły } \\
\text { i posty na blogu; wideo; infografiki; prezentacje i raporty; notatki prasowe; różne } \\
\text { formy komunikacji przez media społecznościowe (Facebook, Google+, Pinterest, } \\
\text { Twitter i YouTube) }\end{array}$ \\
\hline $\mathrm{H} \& \mathrm{M}$ & $\begin{array}{l}\text { Początki marki datuje się na późne lata } 40 \text {. XX w. Obecnie H \& M prowadzi } 3511 \\
\text { sklepów oraz zatrudnia prawie } 93,5 \text { tys. osób w } 38 \text { krajach. Marka doskonale znana } \\
\text { jest na całym świecie. Dla potrzeb firmy zatrudniono najlepszych projektantów, a do } \\
\text { akcji promocyjnych i sygnowania nowych ubrań włączały się takie gwiazdy, jak Ma- } \\
\text { donna, Lana Del Rey czy Donatella Versace. H \& M jest ikoną dobrych jakościowo } \\
\text { ubrań za relatywnie przystępną cenę. Marka H \& M była partnerem dwóch pierwszych } \\
\text { wydarzeń z cyklu Boiler Room w Polsce, z tej okazji przygotowała grę miejską, } \\
\text { w której za pomocą aplikacji mobilnej Snapchat można było zdobyć bilety na eventy } \\
\text { w Warszawie i Krakowie. Akcja polegała na ukryciu biletów w wybranych sklepach } \\
\text { H \& M w Krakowie i Warszawie, przez Snapchata były przysyłane wskazówki w celu } \\
\text { odnalezienia biletu ukrytego w sklepie. Na stronie internetowej sklepu H \& M można } \\
\text { znaleźć zakładkę „wyprzedaż” z przecenionymi produktami. Wchodząc do sklepu } \\
\text { H\&M na witrynie przedstawiającej ubrania z działu dziecięcego, można było dostrzec } \\
\text { informację o promocji } 3 \text { za } 2 \text {. Akcja } 13 \% \text { taniej w piątek } 13 \text {. Rozbudowane działania } \\
\text { merchandisingowe, blog - H \& M magazine, który m.in. służy do budowania wize- } \\
\text { runku marki jako eksperta w swojej dziedzinie przez dobre rady dotyczące ubioru. Ak- } \\
\text { cja - Polacy wyprzedzają trendy, H \& M nie chce zmuszać, nakłaniać do zakupów na } \\
\text { siłę, chce zadowolenia i satysfakcji klientów }\end{array}$ \\
\hline Ikea & $\begin{array}{l}\text { Wizją Ikea jest tworzenie lepszych warunków codziennego życia dla wielu ludzi. } \\
\text { Marka korzysta z reklam internetowych za pośrednictwem narzędzia Google Ad- } \\
\text { Words. Blog „,Ty tu urządzisz” powstał z myślą o fanach Ikea, którzy znajdują na nim } \\
\text { inspirujące artykuły praktyczne, porady i mnóstwo pomysłowych rozwiązań na wnę- } \\
\text { trza dopasowane do ich potrzeb i oczekiwań. Inne formy komunikacji marketingowej: } \\
\text { spoty reklamowe, specjalny kanał na YouTube, różne formy komunikacji przez media } \\
\text { społecznościowe, eventy; autorka Vloga w swoich filmikach na ogół trwających od } 10 \\
\text { do } 15 \text { min krótko prezentuje cykl zakupowy, omawia merchandising w sklepie, uka- } \\
\text { zuje produkty dostępne do kupienia w sklepie Ikea oraz przedstawia pomysły aranżacji } \\
\text { wnętrz; product placement w serialu Rodzinka.pl; katalog firmowy rozsyłany do Po- } \\
\text { laków. Firma organizuje liczne konkursy, które nagradzane są voucherami do wyko- } \\
\text { rzystania w sieci sklepów. Angażowanie konsumentów w różne wydarzenia pomaga } \\
\text { uatrakcyjnić ich odbiór. Różnorodne akcje i przedsięwzięcia z obszarów społecznej } \\
\text { odpowiedzialności i zrównoważonego rozwoju }\end{array}$ \\
\hline
\end{tabular}




\begin{tabular}{|c|c|}
\hline Lidl & $\begin{array}{l}\text { Marka sieci spożywczej. Kampania komunikacji marketingowej z gospodarzami-Do- } \\
\text { rotą Wellman i Karolem Okrasą. Marka zaprasza Polaków do swojej knajpki o znanej } \\
\text { już nazwie kuchnialidla.pl, w której inspiruje do gotowania i poszukiwania nowych } \\
\text { smaków w kuchni. W ramach kampanii o innowacyjnym formacie talk show „Dorota, } \\
\text { Karol i Goście” znana dziennikarka i profesjonalny kucharz wraz z zaproszonymi go- } \\
\text { śćmi gotują w kuchni Lidla, rozmawiają i podsuwają nowe pomysły. Ogólnie marka } \\
\text { Lidl wykonuje kolejny krok w kierunku edukacji i zaangażowania Polaków we } \\
\text { wspólne, domowe gotowanie. Szerokie i profesjonalne działania komunikacji marke- } \\
\text { tingowej, a w tym: reklamy telewizyjne, radiowe, zewnętrzne i internetowe; filmy wi- } \\
\text { deo; portal kulinarny, degustacje; konkursy, eventy, np. obiad z celebrytami, szeroka } \\
\text { komunikacja w internecie, regularnie wydawane gazetki promocyjne; atrakcyjna aran- } \\
\text { żacja w sklepach; ogólnie zintegrowane i multimedialne działania komunikacji mar- } \\
\text { ketingowej }\end{array}$ \\
\hline Orange & $\begin{array}{l}\text { Międzynarodowa marka usług telekomunikacyjnych. Komunikacja marketingowa na } \\
\text { rzecz marki Orange oparta jest na kreatywności, wzbudzaniu emocji, dostarczaniu po- } \\
\text { zytywnych doświadczeń, angażowaniu interesariuszy, ułatwianiu życia i oferowaniu } \\
\text { rozrywki. Bohaterami marki są uczłowieczone maskotki: Serce (kieruje się emocjami, } \\
\text { jest zabawne, trochę nieporadne) i Rozum (racjonalny, opierający się na faktach), obaj } \\
\text { doskonale się uzupełniają i mają wielu fanów, nie sposób ich nie lubić. Zaobserwo- } \\
\text { wane narzędzia komunikacji marketingowej: spoty reklamowe; billboardy; reklamy } \\
\text { telewizyjne, radiowe, zewnętrzne i internetowe; filmy wideo; serwis internetowy } \\
\text { www.orange.pl; promocje tematyczne związane z aktualnymi wydarzeniami; atrak- } \\
\text { cyjne konkursy; eventy; marketing szeptany; szeroka komunikacja w internecie, w tym } \\
\text { w mediach społecznościowych; doradcy klientów w salonach i obsługujący klientów } \\
\text { biznesowych w ustalonych miejscach; regularnie wydawane gazetki promocyjne; } \\
\text { atrakcyjna aranżacja salonów obsługi klientów (zgodnie ze standardami wizualnymi } \\
\text { marki Orange, klimat, muzyka, empatyczna obsługa); wirtualny doradca klienta, info- } \\
\text { linia, czat, blog i profile marki w portalach społecznościowych; wspólne przedsięwzię- } \\
\text { cia promocyjne, np. ,Sony dla ciebie prezent dla domu”- karta home \& you gratis; } \\
\text { ogólnie zintegrowane i multimedialne działania komunikacji marketingowej. Szcze- } \\
\text { gólnie silna kampania światłowodu Orange }\end{array}$ \\
\hline Tymbark & $\begin{array}{l}\text { Marka należy do Grupy Maspex Wadowice i jest obecna na polskim rynku od } 1936 \mathrm{r} \text {. } \\
\text { Za jej komunikację marketingową odpowiada: } 1 \text {. Agencja reklamowa BrainBox; } 2 . \\
\text { Dom mediowy Mindshare (odpowiedzialny za opracowanie strategii, planowanie i za- } \\
\text { kup mediów oraz optymalizację wszelkiego rodzaju kampanii wszystkich marek } \\
\text { Grupy Maspex); 3. agencja TBWA - odpowiada za przygotowywanie i realizację ak- } \\
\text { tywności marki na Facebooku (gdzie jej fanpage ma ponad } 1,5 \text { mln użytkowników), } \\
\text { Instagramie i Twitterze. Niepowtarzalna akcja „Jabłka Tymbark z polskich sadów”, } \\
\text { nagrody za przedsięwzięcia z obszaru marketingu doświadczeń i komunikacji mobil- } \\
\text { nej. Najmocniejsza marka napojowa w Polsce. Jubileusz } 80 \text { lat Tymbarka. Hasła: } \\
\text { "Zawsze przy Tobie”, „Kochaj życie”, ,Tymbark naturalnie do posiłku”. Kampania } \\
\text { "Z Tymbarkiem zawsze jesteś w najlepszym wieku”. Tymbark - główny sponsor naj- } \\
\text { większego w Europie turnieju piłkarskiego dla dzieci - „Z Podwórka na Stadion o Pu- } \\
\text { char Tymbarku” zorganizował konkurs dla wszystkich kibiców. Uczestnicy mają za } \\
\text { zadanie pokazać, jak kibicują swojej drużynie lub ulubionemu piłkarzowi. Doping za- } \\
\text { prezentować można w dowolnej formie - nagrania wideo, zdjęcia lub nagrania audio. } \\
\text { Na najlepsze zgłoszenia czekają nagrody - drony, tablety, bezprzewodowe głośniki } \\
\text { i gadżety kibica (ręczniki, torby i piłki). Akcja jest szeroko wspierana w mediach spo- } \\
\text { łecznościowych, przez Arkadiusza Milika ambasadora Turnieju „Z Podwórka na Sta- } \\
\text { dion o Puchar Tymbarku” oraz przez popularnych w sieci influencerów. Wizerunek - } \\
\text { „marka z tradycją, inne cechy: autentyczność i bliskość. Narzędzia: TV - spoty; druk } \\
\text { - prasa handlowa; eventy, komunikacja czasowa na opakowaniach (okolicznościowe); } \\
\text { intractive - komunikacja przez media społecznościowe, e-mail marketing, SEM/SEO; } \\
\text { handel detaliczny - promocje sprzedaży, merchandising, nośniki POS, video retail- } \\
\text { ment. Budowa wizerunku online nowej marki napojów orzeźwiających Tymbark Next, }\end{array}$ \\
\hline
\end{tabular}




\begin{tabular}{|c|c|}
\hline & $\begin{array}{l}\text { z uwagi na młodą grupę odbiorców, strategia zakładała działania w różnych mediach } \\
\text { online. Finał konkursu w postaci interaktywnej gry odbył się w serwisie YouTube. } \\
\text { W ramach działań przeprowadzona została wizerunkowa kampania display, wsparta } \\
\text { kampanią oraz komunikacją w mediach społecznościowych. „Studio Tymbark” to ka- } \\
\text { nał dla marki prowadzony przez vlogerów SKKF, Jdabrawsky i Banshee, możliwość } \\
\text { publikowania filmów. Do interaktywnego projektu zapraszani będą goście specjalni, } \\
\text { a widzowie będą mieć wpływ na program. Wydarzenie „Kapslowe Walentynki” }\end{array}$ \\
\hline Żywiec & $\begin{array}{l}\text { Grupa Żywiec (15 marek, } 34 \text { produkty, } 11 \text { stylów picia). Szeroka komunikacja marke- } \\
\text { tingowa. Troska o komunikację o cechach: legalna, uczciwa, etyczna oraz zgodna } \\
\text { z zasadami odpowiedzialności społecznej. Cele komunikacji: promowanie odpowie- } \\
\text { dzialnej konsumpcji alkoholu wśród osób pełnoletnich; zwrócenie uwagi na problem } \\
\text { spożywania alkoholu przez osoby niepełnoletnie; promowanie ochrony środowiska na- } \\
\text { turalnego; pielęgnowanie wartości i ikon ważnych dla mieszkańców danego regionu; } \\
\text { identyfikacja społeczeństwa z marką. „Nie lada degustacja” - na stronie internetowej } \\
\text { marki Żywiec można znaleźć konkurs, do wygrania dedykowana szklanka, wystarczy } \\
\text { dodać swoje zdjęcie podczas degustacji jednego z wariantów piwnych marki. Żywiec } \\
\text { - męskie granie, komunikacja czasowa na opakowaniach. Akcja „Lepiej Żywca” jest } \\
\text { częścią kampanii reklamowej prezentującej wartości marki, mieszczace się w sformu- } \\
\text { łowaniu „polski apetyt na życie”. Podczas prowadzonych działań Żywiec ukazuje } \\
\text { swoje nowoczesne, twórcze i wielowymiarowe oblicze. Konsument definiowany jest } \\
\text { natomiast takimi cechami jak energia, ciekawość świata czy odwaga. Konkurs jest tym } \\
\text { samym naturalną konsekwencją tego, co jest dla Żywca ważne - docenia bowiem kre- } \\
\text { atywność, fantazję, pasję i nieszablonowe podejście do życia. Marka Żywiec ma profil } \\
\text { na Facebooku (ponad } 400 \text { tys. obserwujących użytkowników), swoją stronę interne- } \\
\text { tową: http://www.zywiec.com.pl/, na której m.in. ogłaszane są konkursy, także profil } \\
\text { na Instagramie, który śledzi go ponad 3,5 tys. użytkowników. Najważniejsza kampania } \\
\text { „Chce się Ż” przygotowana przez firmy Ogilvy \& Mather, Gong, Just, Roots PR i Me- } \\
\text { diaVest. W tej kampanii w wyjątkowo lekki i inteligentny sposób marka pokazuje } \\
\text { swoje rozumienie apetytu na życie, którym chce zarażać Polaków. Wyjątkowo cie- } \\
\text { kawy spot składa się ze scen przedstawiających różne przejawy nienasycenia życiem, } \\
\text { każda jest podsumowywana hasłem, w którym zamiast słów „Żywiec” i „życie” znaj- } \\
\text { duje się litera „̇̇” }\end{array}$ \\
\hline
\end{tabular}

Źródło: opracowanie własne na podstawie przeprowadzonych badań.

Pozyskane informacje umożliwiły sformułowanie spostrzeżeń i wniosków o działaniach komunikacji marketingowej na rzecz badanych marek. Do ważnych, zaobserwowanych zjawisk należy zaliczyć: budowanie niepowtarzalnego wizerunku marki; tworzenie bohatera marki (ang. brand heros), niejako jej ożywianie i uosabianie, co m.in. pozwala wchodzić z nią w relacje; komunikowanie wartościowych treści; umiejętne nawiązywanie do aktualnych wydarzeń; ukierunkowanie form komunikacji marketingowej na wszystkie zmysły adresata i metodyczne oddziaływanie na niego; wzbudzanie emocji i kreowanie odpowiednich doświadczeń; cykliczne dostosowywanie form, narzędzi i procedur komunikacji marketingowej do współczesnych urządzeń, czy coraz to nowszych funkcjonalności internetu, w tym np. rozwoju mediów społecznościowych i innych możliwości komunikowania się; nacisk na innowacyjność, kreatywność, permanentne zaskakiwanie, inspirowanie, ułatwianie życia; angażowanie celebrytów, blogerów i liderów opinii; respektowanie społecznej odpowiedzialność 
i zrównoważonego rozwoju; realizowanie zintegrowanych kampanii 360 stopni, w kierunku holistycznej komunikacji marketingowej.

\section{Podsumowanie}

Przeprowadzone studia literaturowe i badania empiryczne potwierdziły słuszność tezy, że w drugiej dekadzie XXI wieku komunikacja marketingowa silnie zdeterminowana jest nadążaniem za uwarunkowaniami rynkowymi (w tym m.in. zmianami w zachowaniach i oczekiwaniach adresatów, postępem techniczno-technologicznym oraz rozwojem funkcjonalności oferowanych w internecie), stąd należy ją permanentnie usprawniać oraz dostosowywać do oczekiwań interesariuszy. Metodyczna komunikacja marketingowa na rzecz marki obiektu rynkowego przynosi wiele korzyści zaangażowanym podmiotom - oferentom, klientom, internautom i innym interesariuszom. Postęp techniczno-technologiczny oraz rozwój sieci istotnie wpływają na zachowania nabywców, w tym szczególnie zakupowe. Konsument digitalny wyposażony w urządzenia mobilne w zasadzie ma permanentny dostęp do sieci. Ma umiejętność korzystania z wielu kanałów komunikacyjnych i zakupowych równocześnie stosownie do sytuacji oraz uwarunkowań. Ma także coraz większe możliwości dzięki popularyzacji różnorodnych aplikacji. Ważnymi determinantami skutecznej komunikacji marketingowej na rzecz spersonifikowanej marki są: innowacyjność w połączeniu z kreatywnością, angażowanie interesariuszy, elastyczność, nadążanie za postępem techniczno-technologicznym, cyfryzacją i digitalizacją.

Podsumowując, w obecnych warunkach rynkowych skuteczna komunikacja marketingowa na rzecz spersonifikowanej marki to kompleks działań adresowanych do umysłu, duszy i ciała odbiorcy, który reaguje jednocześnie na wszystkich poziomach: psychicznym, fizycznym i duchowym.

\section{Bibliografia}

Aaker, D.A. (2004). Brand portfolio strategy: creating relevance, differentiation, energy, leverage and clarity. New York: Free Press.

Above the Line (20.04.2016). Wikipedia. Pobrano z: http://pl.wikipedia.org/wiki/Above_the_line. Below the Line (20.04.2016). Wikipedia. Pobrano z: http://pl.wikipedia.org/wiki/Below_the_line.

Bonek, T., Smaga, M. (2013). Biznes na Facebooku i nie tylko. Praktyczny poradnik o promocji w mediach społecznościowych. Warszawa: Oficyna a Wolters Kluwer business.

Brogan, C., Smith, J. (2011). Zaufanie 2.0. Jak wywrzeć wpływ, zdobyć lojalność klientów i kreować markę. Gliwice: Wydawnictwo Helion.

Effie Awards Poland 2011 (2012). Warszawa: Stowarzyszenie Komunikacji Marketingowej SAR.

Gorbaniuk, O. (2011). Personifikacja marki. Perspektywa psychologiczna i marketingowa. Lublin: Wydawnictwo Katolickiego Uniwersytetu Lubelskiego.

Hackley, C. (2010). Advertising \& promotion. An integrated marketing communications approach. London: Sage Publications Ltd. 
Iwankiewicz-Rak, B. (2011). Marketing w organizacjach pozarzadowych - obszary zastosowań. Wrocław: Wydawnictwo Uniwersytetu Ekonomicznego we Wrocławiu.

Janiszewska, K., Kall, J. (2012). Strategia reklamowa. Praktyczny poradnik dla menedżerów marki. Warszawa: PWE.

Kall, J. (2005). Tożsamość marek należących do sieci detalicznych. Poznań: Wydawnictwo Akademii Ekonomicznej w Poznaniu.

Kasprzycki-Rosikoń, J., Piątkowski, J. (red.). (2013). Crowdsourcing. Jak angażować konsumentów w świat marek. Gliwice: Wydawnictwo Helion.

Keller, K.L. (2011). Strategiczne zarządzanie marka. Kapitał marki - budowanie, mierzenie i zarzadzanie. Warszawa: Oficyna a Wolters Kluwer business.

Kotler, PH., Keller, K.L. (2013). Marketing. Poznań: Wydawnictwo Rebis.

O’Guinn, T.C., Allen, C.T., Semenik, R.J. (2012). Advertising and brand promotion. Mason: South-Western Cengage Learning.

Pogorzelski, J. (2015). Marka na cztery sposoby. Branding percepcyjny, emocjonalny, społeczny $i$ kulturowy. Warszawa: Wydawnictwo Wolters Kluwer.

Staszyńska, K.M. (2013). Marka. Konsument. Badacz. Spotkania na rynku. Warszawa: Oficyna a Wolters Kluwer business.

Szufnarowski, J. (20.04.2016). 360 degree campaign. Pobrano z: http://szufnar.pl/360-degree-campaign/.

Taranko, T. (2015). Komunikacja marketingowa. Istota, uwarunkowania, efekty. Warszawa: Oficyna a Wolters Kluwer business.

Tarczydło, B. (2011). Budowanie społeczności wokół marki: wybrane przykłady. Zeszyty Naukowe Uniwersytetu Szczecińskiego, 656, Studia Informatica, 28, 89-100.

Wiktor, J.W. (2013). Komunikacja marketingowa. Warszawa: Wydawnictwo Naukowe PWN.

\section{Trends in Marketing Communication for Brands - Selected Aspects}

Keywords: brand, marketing communication, trends, case studies

Summary. The article aims at providing an overview of directions in development of modern marketing communication activities for the brands. The analysis has been focussed on the following thesis: in the second decade of the 21 st century, marketing communication is strongly determined by keeping abreast of market conditions (including, among other, changes in behaviours and expectations of the target recipients, technical and technological progress, and development of functionalities offered on-line). Starting from an outline of marketing communication activities for the brands of market objects, the article presents current circumstances of their initiation and implementation. Further, the results of desk research have been presented with a summary of available reports and studies on the analysed subject. The article also presents the results of the primary research with the use of case analysis methodology.

Translated by Beata Tarczydło

\section{Cytowanie}

Tarczydło, B. (2016). Trendy w komunikacji marketingowej na rzecz marek - wybrane aspekty. Marketing i Zarządzanie, 4 (45), 381-392. 